Abstracta Iranica Abstracta Iranica

Revue bibliographique pour le domaine irano-aryen

Volume 25 | 2004

Comptes rendus des publications de 2002

\title{
Before Taliban. Genealogies of the Afghan Jihad. University of California Press, 2002, 354 p.
}

\section{Tchanguiz Pahlavan}

\section{Q OpenEdition \\ 1 Journals}

Édition électronique

URL : http://journals.openedition.org/abstractairanica/4702

ISSN : 1961-960X

\section{Éditeur :}

CNRS (UMR 7528 Mondes iraniens et indiens), Éditions de l'IFRI

\section{Édition imprimée}

Date de publication : 15 mai 2004

ISSN : 0240-8910

\section{Référence électronique}

Tchanguiz Pahlavan, «Before Taliban. Genealogies of the Afghan Jihad. University of California Press, 2002, 354 p. », Abstracta Iranica [En ligne], Volume 25 | 2004, document 192, mis en ligne le 15 mars 2006, consulté le 25 septembre 2020. URL : http://journals.openedition.org/abstractairanica/4702

Ce document a été généré automatiquement le 25 septembre 2020.

Tous droits réservés 


\title{
Before Taliban. Genealogies of the Afghan Jihad. University of California Press, 2002, $354 \mathrm{p}$.
}

\author{
Tchanguiz Pahlavan
}

1 According to the author, this is a book about the Marxists and their enemies. His objective is to contextualize the history of the present in the history of the past, in order to evaluate what happened in Afghanistan. To attain this objective the author tries to frame his own exercise in historical understanding in genealogical terms. He believes that friendship, authority, love, and even enmity are volatile until they have been transmitted into genealogical form, which traditionally is the apparatus with which Afghans - particularly tribal Afghans - think and upon which they act. Therefore, his analysis is based on a genealogical approach to Afghan history. As a result, he wants to look at individual lives and try to understand their connection to larger historical and cultural processes.

2 Since, according to the author, in all that has been written about the war in Afghanistan, there has been little of note about individuals or about the war seen from ground level, he wishes to pay attention to this aspect of Afghan society, but not to look at the lives of "ordinary people". Although he believes that attention should be paid to the experiences of noncombatants, women in particular, he concedes that he has not been able to produce such a work.

3 The author wants to look at the origins of events. He says genealogies are about the origins, about how things got to be the way they are, based on the way they "originally" were. He uses the genealogical method to try to uncover the origins of the Jihad, starting with the communist takeover and then with the Islamic uprising against it. It is quite questionable whether his story gives a comprehensive new account of the history of Afghanistan or a new way of looking at it. Even individuals selected for this method do not represent the variety of Afghan society. 
INDEX

Thèmes : 4.4. Histoire de l'Afghanistan (à partir de 1747)

\section{AUTEURS}

TCHANGUIZ PAHLAVAN

Münster 